\title{
Analysis Of Food Diversification Policy In Overcoming The Food Crisis
}

\author{
Ika Widiastuti, Himawan \\ iwidiastuti86@gmail.com, himawanawan10@gmail.com \\ Krisnadwipayana University, Raharja University \\ Received: 26 April 2021; Revised: 16 July 2021; Accepted: 13 August 2021 \\ DOI: http://dx.doi.org/10.37905/aksara.7.3.999-1008.2021
}

\begin{abstract}
The food crisis is a threat to all countries. Thinking must be changed from food security to food self-sufficiency. The policy in overcoming the food crisis is by diversifying food. Food diversification is food diversification with balanced nutrition. Barriers to the development of local food are undeveloped products and people's thinking that rice is a staple food. The development of local food products is the provision of income for the food industry.
\end{abstract}

Keywords: food diversification, food crisis, local food

\section{Introduction}

Food is an important factor for national resilience. The threat is the world food crisis caused by reduced food and land production. Rising food prices are caused by insufficient food and an increasing population which will result in rising inflation. The way to deal with inflation is to stabilize food prices and stocks. Securing and increasing food stocks is an effort to prevent an increase in the inflation rate. In 2011 food production decreased compared to 2010 , rice $1.63 \%$, maize $5.99 \%$ and soybean $4.08 \%$. The decline in production resulted in a sharp increase in food imports. From 2010 to 2011, rice imports were about 2.2 million tons, in October 2011 rice imports were 1.4 million tons, while imports of wheat were 6.7 tons, corn 1.5 tons and soybeans 4.7 tons. With the data above, it can be seen that food land is reduced so that food production also decreases which results in inflation so that it requires dependence on food imports.

Rice is a mandatory food. A balance is needed between population and rice production. The rice producing provinces are Lampung, Sumatra, Sulawesi, and Java. 
Picture 1. Comparison of Rice Production and Population and Comparison of Rice Consumption and Availability

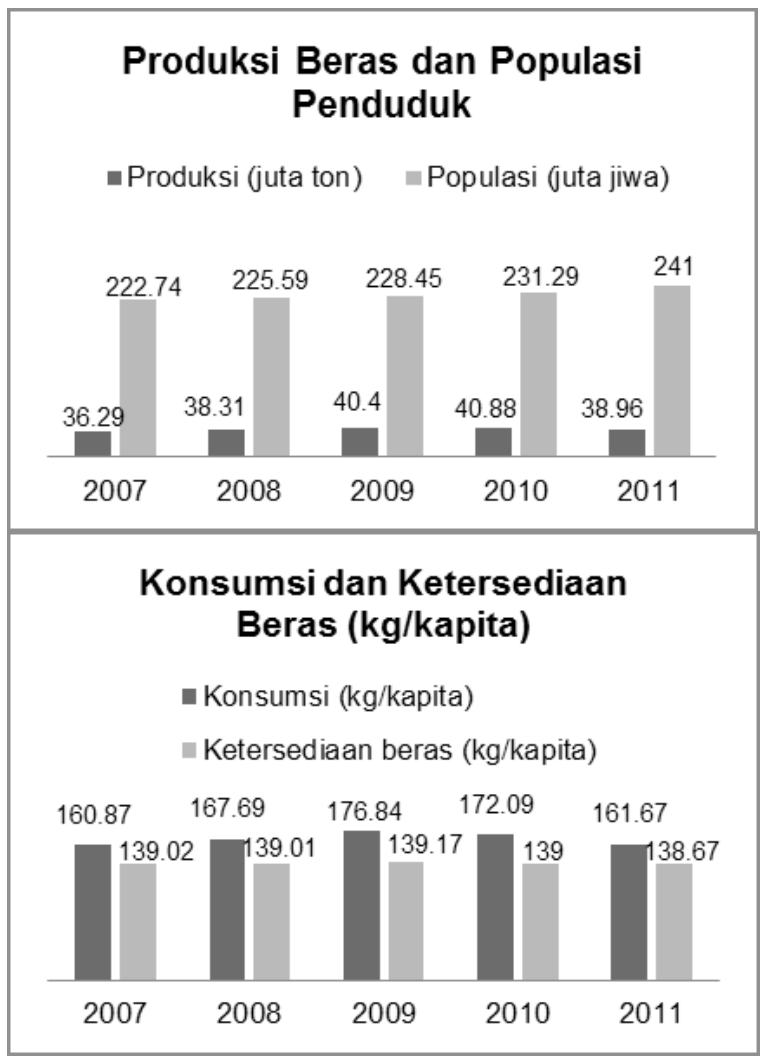

Source: BPS

As a food commodity, rice consumption has increased annually. The population of Indonesia has always been increasing, while rice production has decreased due to changes in the use of agricultural land for industrial activities, changes in weather, and rising prices for agricultural facilities and infrastructure.

Figure 1 shows that the increase in rice availability has not been able to compensate for the high consumption of rice from the community. Imports of food, especially rice and wheat, will increase if the population increases but the amount of food production decreases. Strategies to overcome domestic food shortages by importing food. However, food imports that are carried out continuously will result in dependence on other countries and have an impact on the nation's resilience to become fragile. The threat of a world food crisis must be addressed immediately and strive to meet the country's needs.

\section{Literature review \\ Food security}

Food security is important, especially for the Indonesian population. The population is estimated to increase by around 270 people in 2025 . Food security is related to production costs, economic stability and political stability. The activities of implementing food security are aimed at national development. The definition of food security according to Maxwell and Frankenberger (1992) is that to live a healthy life, sufficient food is needed. 
According to Mercy Corps, food security is that it is easy for everyone to access sufficient, nutritious and safe food for a productive and healthy life socially, economically and physically.

The factors needed in food security are:

1. individual oriented,

2. Availability of food and easy access,

3. Access to food economically, physically and socially,

4. adequate nutrition,

5. Healthy and productive life.

Food security consists of various elements, namely available food, stable food prices, and easy access. All elements of food security must be met. Food must be fulfilled at the regional, national level and have easy access to the community in order to meet food needs which is carried out evenly, so as to strengthen food security. In addition, to strengthen food security, a strategy is needed, namely food must be distributed to rural areas.

\section{Food Sovereignty}

The seven principles of food sovereignty according to Via Campesina are food, which is the basic right of every human being; apply the Agrarian Reform approach; responsible protection of natural resources; orderly food market; peace; can tackle global hunger and control democracy. Food sovereignty has become a food security paradigm and is part of agricultural development. Food sovereignty has a broader meaning than food security.

Food sovereignty consists of:

1. Prioritizing regional agricultural production,

2. Producing food is the right of the farmer, while determining the food to be consumed is the right of the consumer.

3. Stabilizing the prices of imported food and agriculture,

4. Determine the cost of food import tax,

5. Determine agricultural policies by the people,

6. Recognition of agricultural and food production.

Food sovereignty makes a country have full authority and the ability to meet the food needs of its population. Food sovereignty is determined by the local population. Food sovereignty aims to overcome the food crisis, food production that has not been fulfilled due to climatic factors. Excessive food imports and exports of food are caused to obtain foreign exchange not the flow of a food-sovereign country.

\section{Food Independence}

Food is determined in accordance with Law No. 18 of 2012, the government is tasked with meeting the food needs of the community. The success of national development is determined by the fulfillment of quality human resources. The independence policy aims to fulfill food needs. Food independence can be done if the increase in production and marketing efficiency can be adequate. 


\section{Food Diversification}

The way to increase food consumption with various kinds of food is called food diversification. Food diversification consists of diversification of food production, availability, and consumption.

Food diversification has been echoed since Presidential Instruction 14 of 1974 concerning Improvement of the People's Food Menu (PMMR) in order to increase food diversification and quality in the context of national development.

Food diversification to overcome dependence on food imports and rice consumption. To overcome this, it is necessary to develop local food. How to diversify food, namely

1. Internalization, socialization, promotion, and publication,

2. Availability of local food

3. Increasing the capacity and capacity of human resources,

4. Community empowerment,

5. Monitoring of food diversification activities.

Food diversification is related to nutrition, quality of human resources and health. Diversification of food consumption is consuming a variety of nutritious and balanced foods according to their quantity and quality.

Diversification of food production must be balanced with diversification of food availability and consumption. Diversification of food production by producing food must be made from cassava or cassava.

The dimensions of food security are food that is available, has easy access and is continuous. Food security is related to food diversification because food must be available more widely so as to increase the three dimensions of food security.

\section{Food Crisis}

The financial crisis coincided with the energy crisis and the food crisis. High world crude oil prices can lead to high food prices.

Food problems include:

1. increase in oil prices,

2. The phenomenon of climate change that can affect global food production and stocks,

3. Global food demand is increasing due to the increasing population,

4. Movements in food prices on international markets coupled with the global financial and economic crisis have had an impact on domestic food markets and prices.

The most effective way to overcome the food crisis is food self-sufficiency and food sovereignty (diversification of food availability, production, and consumption). Only depending on the production of one type of food source causes food independence and sovereignty to experience difficulties so that it has not been able to keep up with the increasing population.

\section{Results and Discussion \\ Policies in Anticipating Food Crisis}

The food crisis is a threat to the world. The world food crisis occurs due to an increasing population while food production has decreased. In addition, the food crisis occurred due to the increase in the food price index. 
The causes of the world food crisis are the increasing number of people, food commodities are used for fuel, and the increasing welfare of the population has an impact on increasing food production which can cause food consumption to increase.

It is hoped that the government can overcome the food crisis and build sustainable agriculture. Food security in developing countries makes exporters become importers.

Figure 2. Import of Food Crops Commodities 2008-2011 Quarter I

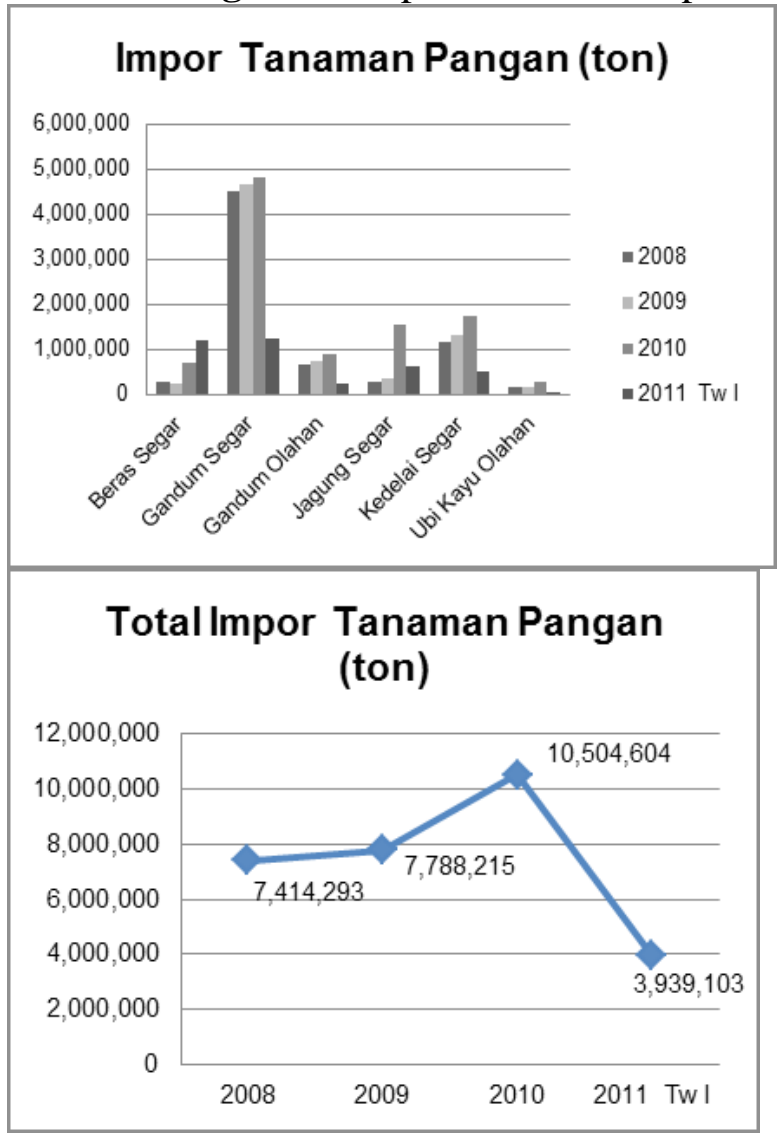

Source: BPS 2011

Imports of food crops, especially wheat, rice, and fresh corn from Figure 2 show that there was an increase from 2008 to 2011 in the first quarter of 2011. In 2008 the total imports of food crops was 7.4 million, while in 2010 it increased by $70 \%$. With the increase in food imports so that they can carry out decision making to be able to maintain food security.

Food security emphasizes food availability, consumption and food production. These three factors are interrelated and must be met for food security. Food availability is the cause of increased imports of food crop commodities, especially from 2009, 2010 and 2011. Imports are carried out to strengthen and realize national food security. To overcome the food crisis, the way that must be implemented is to carry out food imports.

Continuous import policies will result in Indonesia's food dependence on other countries. At the time of the world food crisis, all countries prioritized fulfilling their country's food needs and limiting the export of food crop commodities. Imports of food crops at lower prices than domestic food prices result in farmers being less protected and disadvantaged so that food crop production is reduced. 
Figure 3. Population Development in 2000-2010 and Indonesian Rice Production in 2008-2011
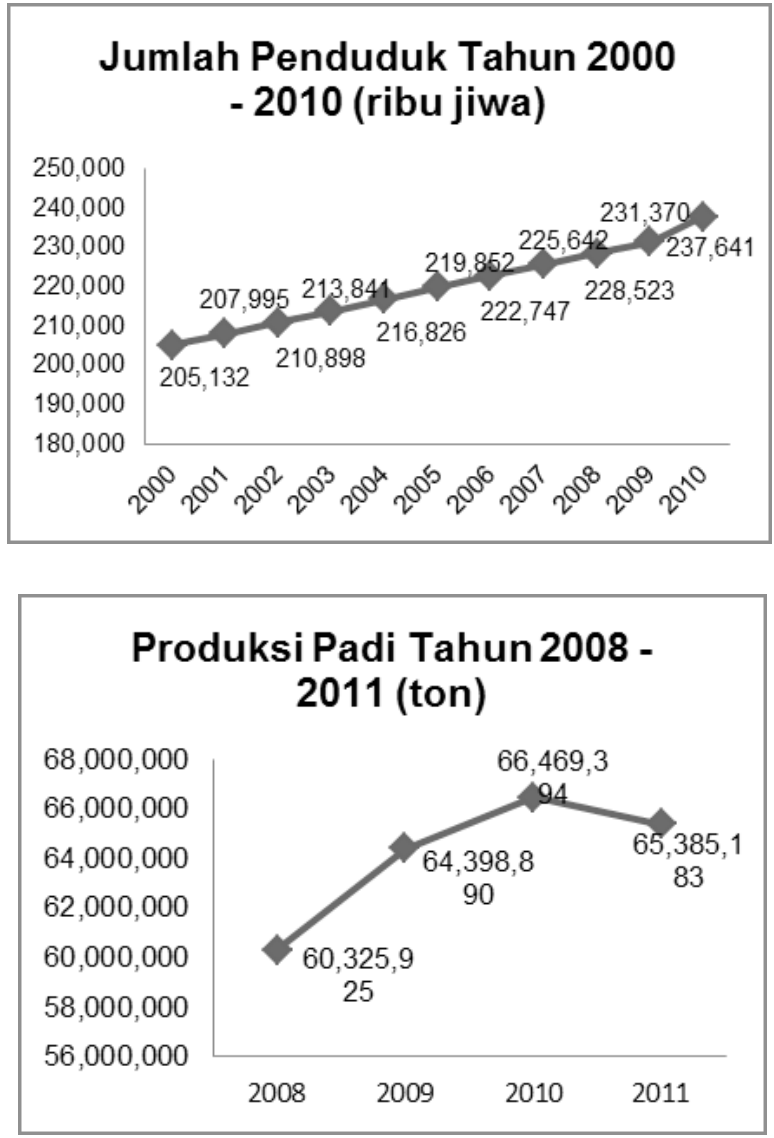

Source: BPS, 2011.

Based on Figure 3, from the demand side, Indonesia's food needs have increased because the population is quite high each year on average 3,076.95 thousand people until 2010 amounting to 237,647 thousand people. Based on these data, from 2010 to 2011, rice production decreased.

Rapid population growth and experts in the function of productive land into land not for food crops must be addressed immediately. The conversion of productive land will result in a decrease in food crop production and will result in imports. To overcome the world food crisis is to change the paradigm of food security into food sovereignty and farmers that lead to food self-sufficiency. Food sovereignty gives a country full rights to determine domestic food policy. An increase in food imports will disrupt food selfsufficiency. Ways for food self-sufficiency and realizing national food security are increasing supply and smooth distribution, post-harvest systems, use of science and technology, assistance for seeds, implementation of policies for purchasing grain prices and subsidizing farm loans.

In increasing food self-sufficiency, namely by increasing rice import tariffs so that it can increase national food security, while trade liberalization results in a decrease in rice food independence. Food problems in Indonesia are the increasing number of poor 
people, insufficient food production, mandatory food consumption focused on rice, the lack of development of local food diversification.

In overcoming food insecurity and realizing food security, namely by diversifying food. Development of food diversification for farming. The development of local food diversification can increase income and employment. Food diversification strategies, namely the development of agricultural resources, and increasing the comparative advantage of agricultural resources, developing the entire agribusiness chain, increasing research and development on food and nutrition, developing food quality and distribution; the use of the relative price policy of the agricultural sector and farmers are free to determine the crops they choose; development of traditional food types; and perform food analysis.

\section{Opportunities in Realizing Food Diversification}

Indonesia, which produces non-rice food crops such as corn, soybeans, peanuts, green beans, cassava and sweet potatoes, is the development of local food diversification. When an island that is not a rice production center experiences a food crisis, it takes time to distribute the food. This can be overcome with local food-based diversification policies or food diversification. Cassava and corn are food crops with the largest production amount compared to other commodities and have great opportunities to be developed into local staple foods.

Figure 5. Production of Non-Rice Food Crops in 2007-2011

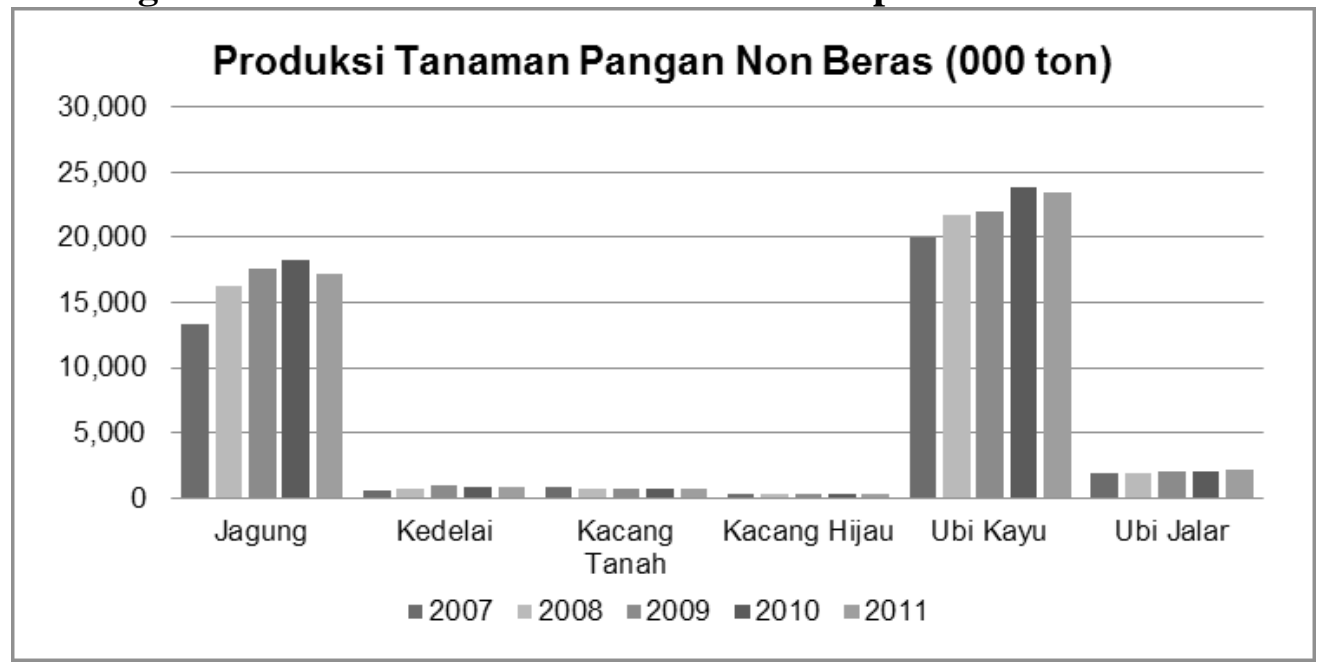

Source: BPS, 2012.

Production of non-rice food crops such as Figure 5, corn and cassava has a fairly high production compared to other non-rice food crops so that it can be used as an alternative food other than rice. Corn and cassava as a solution for national food diversification/food diversification. Food diversification consists of types, materials and forms of food. In the national development program, it is necessary to diversify food called horizontal and vertical diversification. Horizontal diversification is the development of agricultural cultivation diversification such as corn, sweet potatoes, sago, and so on, while vertical diversification is the development of various food products such as flour, biscuits, cakes. 
The development of food diversification in Indonesia has not run optimally. The increasing number of instant food products made from wheat, such as noodles, biscuits, bread, and other foods resulted in reduced rice consumption followed by an increase in wheat consumption. Rice consumption in Indonesia is still very large so that the achievement of the Expected Food Pattern ( $\mathrm{PPH}$ ) has not been maximized because consumption is still dominated by rice. The decrease in rice consumption should be followed by an increase in local food consumption instead of wheat consumption. The tendency of people to choose instant noodles is triggered by the price of products that are relatively affordable and easy to obtain. Obstacles in the development of local food are products that cannot be developed, cannot be easily reached and public opinion that rice is a mandatory food that must be consumed.

Changes in eating habits depend on economic, cultural and social circumstances. The factor that causes dynamic eating habits is public acceptance of existing food ingredients. Global trade is contributing to new food processes. Changes in people's eating are dynamic because there are changes according to the times. The development of local food products must be in accordance with regional production supported by the Regional Government so as to reduce dependence on staple food, namely rice. The development of local food should be adapted to the production of each region so that each region has different local food and is able to meet its food needs independently.

Food consumption diversification must be balanced with local food availability and production diversification. In Indonesia, the development of staple foods based on local ingredients is still very possible. There are still many non-rice food crops that have not been utilized optimally, such as cassava and corn that can still be developed into more attractive foods. Research and technology regarding local food production must be improved and developed so that local food products are of good quality, good and attractive, especially for food.

\section{Conclusion}

In 2008 the government was able to increase production but experienced difficulties in production. High land conversion, increasing population, rising food prices are the causes of the food crisis.

The government is expected to implement sustainable agriculture. Food security can change the paradigm from exporting countries to importing countries for developing countries.

An increase in food imports can hamper food self-sufficiency. The development of local food diversification is a way of overcoming food insecurity and realizing food security.

To realize food security and develop farming, it is necessary to develop food diversification. Reduced food consumption can reduce rice consumption per capita to support developments towards a hopeful food pattern.

The obstacles in developing local food are that the product has not been developed and has not been reached by the community and the opinion of the community that rice is a mandatory food. 


\section{Bibliography}

Arifin, B. 2005. Agricultural Development Policy Paradigm and Revitalization Strategy. Jakarta: PT. Grasindo.

Hanafie, R. 2010. Introduction to Agricultural Economics. Yogyakarta: CV. Andi Offset. Josef, P. Widyatmadja. 2005. Nationality and Globalization in Diplomacy. Yogyakarta: Kanisius.

Laswai, HS, et al. "Improvement and Popularization of Diversified Cassava Products for Income Generation and Food Security: A Case Study of Kibabu". African Journal of Food Agriculture Nutrition and Development, 6(1), 2006, pp. 1-15.

Prasetyantoko, A. 2008. Financial Disaster. Jakarta: PT. Kompas Media Nusantara.

Rachman, HPS and Mewa. A. Diversification of Food Consumption in Indonesia: Problems and Implications for Policies and Programs. Agricultural Policy Analysis, 6(2), 2008, p. 140-154. ., et al. Impact of Trade Liberalization on National Food Security Performance. Agricultural Innovation Development, 1(1), 2008, p. 47-55.

Setiawan, U. Dynamics of Agrarian Reform in Indonesia in Two Centuries of Land Tenure. Jakarta: Indonesia Obor Foundation, 1984. Simatupang, P. Critical Analysis of Paradigms and Basic Framework for National Food Security Policy. Agro-Economic Research Forum, 1, 2007, p. 1-18.

Tajuddin, B. Cassava-Based Food Security. Food, 19(1), 2010. 
AKSARA: Jurnal Ilmu Pendidikan Nonformal

P-ISSN 2407-8018 E-ISSN 2721-7310 DOI prefix $\underline{10.37905}$

Volume 07, Issue 03 September 2021

http://ejurnal.pps.ung.ac.id/index.php/Aksara 